\title{
Role of agmatine in the application of neural progenitor cell in central nervous system diseases: therapeutic potentials and effects
}

\author{
Renée Kosonen $^{1,2}$, Sumit Barua ${ }^{1}$, Jong Youl Kim ${ }^{1}$, Jong Eun Lee ${ }^{1,2}$ \\ ${ }^{1}$ Department of Anatomy, Yonsei University College of Medicine, Seoul, ${ }^{2}$ Brain Korea 21 Plus Project for Medical Science, Brain Research Institute, \\ Yonsei University College of Medicine, Seoul, Korea
}

\begin{abstract}
Agmatine, the primary decarboxylation product of L-arginine, generated from arginine decarboxylase. Since the discovery of agmatine in the mammalian brain in the 1990s, an increasing number of agmatine-mediated effects have been discovered, demonstrating the benefits of agmatine on ischemic strokes, traumatic brain injury and numerous psychological disorders such as depression, anxiety, and stress. Agmatine also has cellular protective effects and contributes to cell proliferation and differentiation in the central nervous system (CNS). Neural progenitor cells are an important component in the recovery and repair of many neurological disorders due to their ability to differentiate into functional adult neurons. Recent data has revealed that agmatine can regulate and increase proliferation and the fate of progenitor cells in the adult hippocampus. This review aims to summarise and discuss the role of agmatine in the CNS; specifically, the effects and relationship between agmatine and neural progenitor cells and how these ideas can be applied to potential therapeutic application.
\end{abstract}

Key words: Agmatine, Neural progenitor stem cells, Arginine, Neuroprotection, Therapeutic uses

Received April 29, 2021; 1st Revised May 25, 2021; 2nd Revised May 28, 2021; Accepted May 31, 2021

\section{Introduction}

Agmatine was first discovered in 1910 and was long thought to be a component of bacteria, plants and select invertebrates $[1,2]$. However, the discovery of agmatine being expressed in rat brains in the 20th century indicated that mammalian agmatine is synthesized and not a result of diet or bacteria growth [1]. Agmatine is the primary endogenous peptide that is synthesized via the decarboxylation of L-arginine, which originates from arginine decarboxylase (ADC), then

\footnotetext{
Corresponding author:

Jong Eun Lee (1)

Department of Anatomy, Brain Korea 21 Plus Project for Medical Science, Brain Research Institute, Yonsei University College of Medicine, Seoul O3722, Korea

E-mail: jelee@yuhs.ac
}

hydrolyzed by agmatinase [2-4]. It can be found abundantly in the stomach, small intestines, aorta and throughout the brain and spinal cord, although in significantly less concentration [5]. As depicted in Fig. 1, the role and concentration of agmatine in the central nervous system (CNS) is region specific. The highest concentration of agmatine is found in the gastrointestinal tract; this is mainly due to dietary ingestions and local synthesis of gut microflora [6-8]. In the gastrointestinal tract, agmatine is believed to work as an inverse agonist on receptors which results in hypertension and exacerbated gastric mucosal injury $[8,9]$. Agmatine plays a role in maintaining homeostasis in the brain, heart and surrounding vascular structure by modulating calcium levels $[5,10$ 13]. Agmatine affects many cellular mechanisms in the CNS such as cellular apoptosis, regulation of inflammation, and neural edema. It has been shown to inhibit the formation of advance glycation-product, which is known to damage the

\section{Copyright ( 92021 . Anatomy \& Cell Biology}

This is an Open Access article distributed under the terms of the Creative Commons Attribution Non-Commercial License (http://creativecommons.org/licenses/by-nc/4.0/) which permits unrestricted non-commercial use, distribution, and reproduction in any medium, provided the original work is properly cited. 


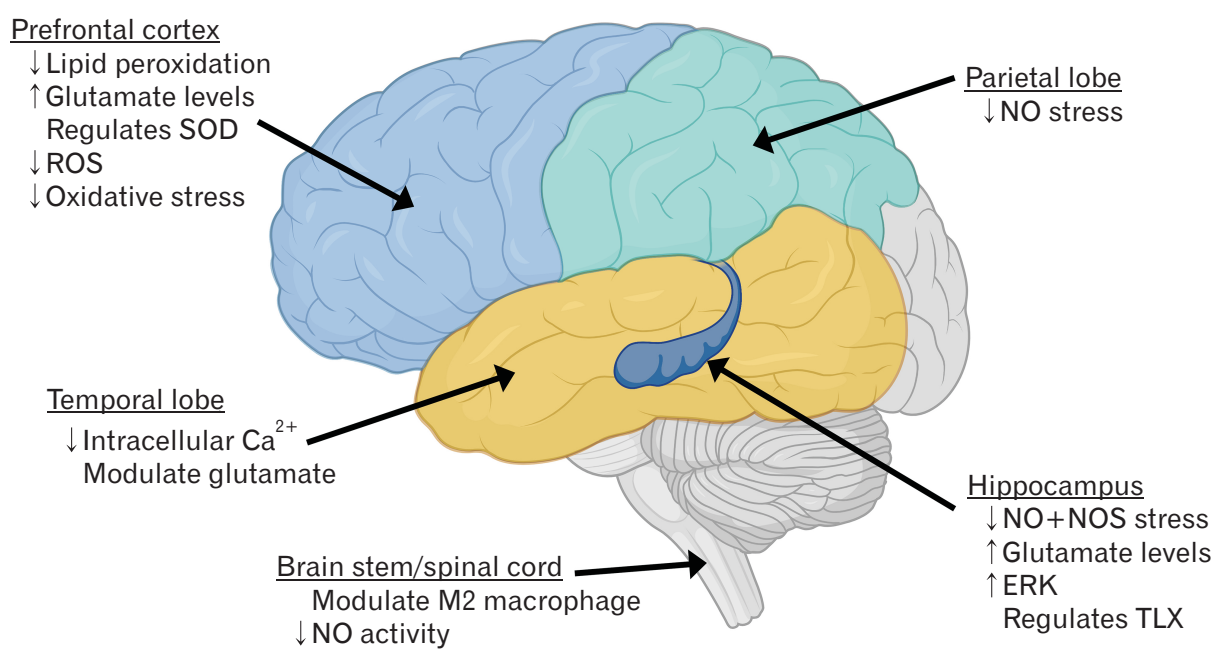

Fig. 1. Schematic diagram of the roles of agmatine in the brain stem/spinal cord, hippocampus, temporal lobe, prefrontal and parietal lobe. ERK, Extracellularsignal-regulated kinases; NO, nitric oxide; NOS, nitric oxide synthase; ROS, reactive oxygen species; SOD, superoxide dismutase; TLX, tailless homolog. This figure was created and published with permission from BioRender.com. extracellular protein, leading to many neurodegenerative diseases [14]. Agmatine has been shown to have a regulatory effect on the fate of, proliferation and differentiation of neural progenitor cells in the adult hippocampus, by modulating regulatory functions of neurogenesis such as nitric oxide synthase (NOS) stress and glutamate levels $[9,13]$. The main roles of agmatine in the mammalian body are thought to modulate functions associated with cell membrane and cytoplasmic targets including neurotransmitters, N-methyl-Daspartate (NMDA) receptors, ion channels, and nitric oxide (NO), either directly or indirectly (Fig. 1) [1-4, 15, 16].

\section{Agmatine: Overview and Biological Significance in the Central Nervous System}

The literature regarding agmatine has drastically increased over the last decade with a wide range of neurological focuses such as ischemic stroke, epilepsy, and psychological disorders such as stress, depression, and addiction $[2,9$, 17-19]. Recent studies have shown that agmatine protects neurons against glutamate toxicity by inhibiting the production of NO in microglia; this mechanism is controlled by NMDA receptors [20-24]. It has also been proposed that the agmatine related blockades of NMDA receptors may have an underlying antidepressant and anti-anxiety effect, which will be discussed later $[9,16,23,25]$. Agmatine has been shown to protect neural tissue from ischemic insult by inhibiting NO signaling because of its structural similarities to L-arginine, making it a competitive NOS inhibitor [26]. Agmatine affects many cellular mechanisms in the CNS and has a unique role throughout the body. Targeting agmatine and its metabolites

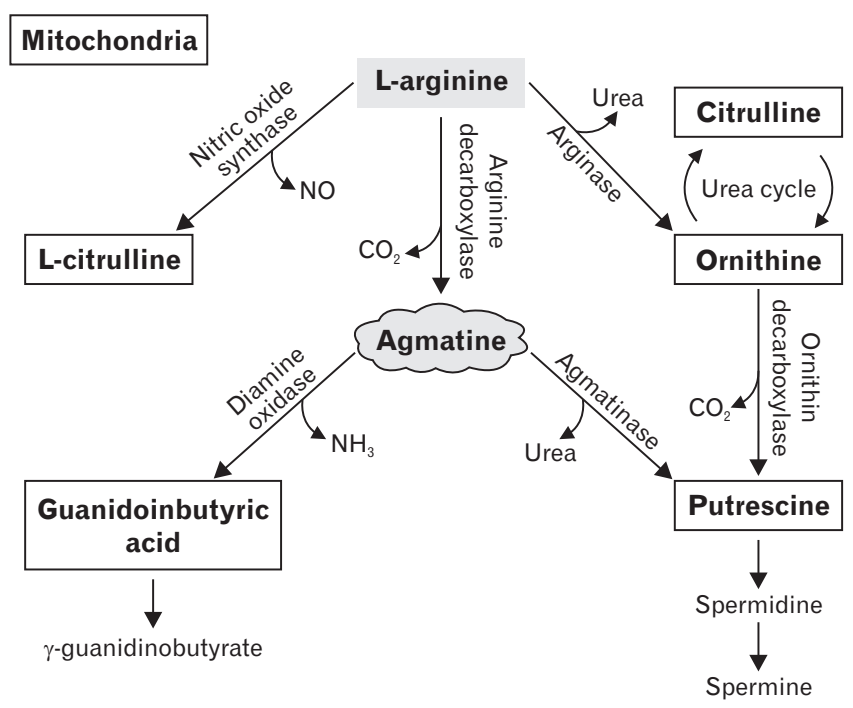

Fig. 2. Schematic illustration of the synthesis of L-arginine dependent, agmatine in the mitochondria of astrocytes. Agmatine is synthesized as a result of arginine decarboxylase dependent L-arginine. Arginase converts L-arginine to ornithine, which enters the urea cycle and NOS initiates the conversion of L-arginine to $\mathrm{NO}$ and citrulline. Agmatine can be metabolized to putrescine-which can produce spermine and spermidine - through agmatinase or be oxidised by diamine oxidase to produce guanidinobutyric acid. NO, nitric oxide.

is a platform that future researcher can work from to gather a better understanding of the exact cellular mechanisms and their related effects, which will be further discussed.

Since the discovery of agmatine in the mammalian brain, it has been confirmed that agmatine is produced in the cortex and brain stem of the brain and also in the spinal cord, then stored and synthesized in astrocytes $[1,3,17]$. Larginine can be found abundantly in astrocytes, which are 
the prominent glial cell in the brain, also expressing enzyme systems that metabolize arginine [15, 27]. L-arginine enters the pre-synaptic ending where it is decarboxylated via mitochondrial ADC to produce agmatine $[1,17]$. The agmatine product is then stored in the synaptic vesicles of astrocytes, ready to be released by the depolarization of $\mathrm{N}$-type $\mathrm{Ca}^{2+}$ ion channels, which remain inactivate due to the reabsorption and degradation by agmatinase [17].

Agmatine and its metabolites have an influential effect on many cellular mechanisms throughout the body, including how they are synthesized. As illustrated in Fig. 2, the process of synthesizing agmatine through ADC is L-arginine dependent, the substrate for arginase and NOS (Fig. 2) [27]. Arginase hydrolyses L-arginine to ornithine, which enters the urea cycle, where NOS initiates the conversion of L-arginine to NO and L-citrulline [3, 4]. Agmatine can be metabolized to putrescine, through agmatinase [28]. Ornithine and agmatine are hydrolyzed by agmatinase to create putrescine, a precursor of spermine and spermidine [17]. Spermidine is essential for the biosynthesis of pro-insulin, while spermine may exert a stimulatory effect on long-term insulin release and RNA transcription [28]. Another significant metabolic pathway of agmatine, prevalent in the periphery cycle, is that agmatine can be metabolized into guanidinobutyric acid by the enzyme diamine oxidase, which is then oxidized to $\gamma$-guanidinobutyrate (Fig. 2) $[3,4,17,28]$. There is evidence to suggest that agmatine can be characterized as an inhibitory subunit for monoamide oxidase, an important neurotransmitter regulator, when administered in high concentrations (167M) [29]. NOS has been shown to be competitively inhibited by agmatine in vitro, which has a substantial impact on the function and actions of agmatine in the mammalian brain [17, 30-32].

Both endogenous and exogenous agmatine can exert their functions on $\mathrm{NO}$ and reduce ischemic brain injury in neonatal rats, levels of both are also increased during ischemic insults [33, 34]. Kim et al. [32] demonstrated the neuroprotective functions of agmatine, both in vivo and in vitro through reducing the production of $\mathrm{NO}$ by competitively inhibiting neuronal NOS (nNOS) and isoform NOS (iNOS). ADC is localized in astrocytes, so endogenous agmatine production is thought to be predominantly in astrocytes which are mainly absent in in vivo studies involving cultured neurons. This is hypothesized to be the main reason that there is such a discrepancy in the neuroprotective effects of agmatine in, in vivo and in vitro studies [32]. Moreover, it has also been demonstrated that exogenous agmatine can inhibit the expression of metalloproteinase-2 (MMP-2) and metalloproteinase-9 (MMP-9), a protein that plays a pivotal role in the integrity of the blood-brain barrier which is essential for cerebral homeostasis [3, 26, 32, 35]. Jung et al. [36] investigated endogenous agmatine on inhibiting the expression of MMP2 and MMP-9 by induction of endothelial NOS (eNOS) in vitro. The findings suggested that endogenous agmatine is able to reduce the expression of MMP-2 and MMP- 9 by regulation of eNOS, NO and the activation of transcription factor 3 [35, 36]. Excess agmatine that is produced endogenously, protects neural progenitor cells from hydrogen peroxide injury; however, the exact mechanisms of this process are not yet confirmed [34, 37, 38]. Agmatine has a diverse and influential role throughout the CNS, with many of its capabilities still not fully understood. Exogenous and endogenous agmatine also have a great influence on the proliferation or differentiation ability of neural progenitor cells in the mammalian brain, which we will discuss in more depth in this paper.

\section{Properties of Neural Progenitor Cells}

Neurogenesis is known as the functional generation of neurons and glial cells from neural progenitor cells in the CNS, primarily occurring in the subgranular zone of the dentate gyrus $[39,40]$. Neural progenitor cells are known as the progenitor cells that give rise to almost all of the glial and neuronal cell types within the CNS $[39,41]$. They are most active in the early embryonic and perinatal stages, originally thought to be the only active phases [39-42]. However, it has since been discovered that neurogenesis continues into adulthood in the subgranular zone of the dentate gyrus in the hippocampus and in the subventricular zone of the lateral ventricles [40, 42]. These newly generated neurons migrate through the rostral migratory stream to the olfactory bulb to differentiate into functional neurons [43]. It is crucial to identify a viable source of neural progenitor cells, that is able to differentiate into neural like cell, because it is challenging to regenerate nervous tissue after insult. The process of identifying viable sources of neural progenitor cells from various sources, to promote neurogenesis post CNS injury. Recent studies have also identified human dental pulp stem cells as a promising candidate for stem cell therapy as they differentiate in to neuron like cells $[44,45]$. These stem cells were derived from ectomesenchyme neural crest, which means they have the similar characteristic to that of mesenchymal and 
neural crest stem cells $[45,46]$. Under normal physiological conditions, adult neurogenesis in other regions of the CNS is extremely limited; however, evidence has emerged that it can be induced after neuronal insult [40, 47-49]. The presence and degree of neurogenesis in the adult dentate gyrus had been linked to crucial cognitive behaviors such as learning, memory retention and pattern recognition, both in normal and diseased states $[47,48,50]$.

Neurogenesis of progenitor cells is a complex process that involves proliferation, migration, differentiation and functional integration. Post neuronal insult, be that traumatic or stroke, the migration of neural progenitor cells increases in the tissue lesion [51]. The adaptive mechanism of neuroplasticity is an integral part of the recovery process of brain and cognitive function after cerebral injury [52]. Stress-related phycological diseases such as bipolar disorder, depression and anxiety have been associated with the downregulation of neurogenesis in the adult hippocampal region $[23,53]$. Adult neurogenesis has been linked to having an antidepressant effect in mice and also reducing stress levels and improving the overall emotional state of the animal $[9,54,55]$. It has been observed that in stressed induced mice, agmatine could prevent the suppression of neural progenitor cell proliferation in the subgranular zone $[9,31]$. Agmatine can modulate long term activity-dependent neuroplasticity in rodents, by blocking NMDA receptors and increasing proliferation of neural progenitor cells [56]. These discoveries suggest that agmatine can induce the proliferation of neural progenitor cells, by blocking NMDA receptors, which is important in the recovery of CNS diseases.

\section{The Role of Agmatine on Neural Progenitor Cells in the Central Nervous System}

Agmatine has also been considered as a neurotransmitter due to being heavily localized in the pyramidal cell bodies and granule cells of the dentate gyrus and has a modulative effect on learning and memory $[5,57,58]$. Recent studies have investigated the levels of agmatine in the hippocampus of rats throughout the learning and activity phases of the performance during the Morris water maze task [28, 59]. In one study, the animals that displayed an increase in their learning curve also showed an increase in glutamate and agmatine levels in the hippocampal region, proposing that endogenous agmatine system can be controlled during the learning and activity phases [28]. Rushaidhi et al. [59] com- pleted a study investigating hippocampal agmatine levels in rodents throughout phases of cognitive testing. There was a significant (78\%) increase in agmatine levels in the hippocampal agmatinergic synaptic terminals after the spatial learning phase [58]. These results are consistent with other studies on the role of agmatine in spatial learning, indicating that endogenous agmatine can modulate the learning process by working in conjunction with glutamate as putative neurotransmitters $[28,58,59]$.

The use of neural progenitor cells overexpressing ADC in animal models can promote the formation of synapses and the recovery of motor function following cerebral ischemia [37]. Indicating that this process is a promising candidate for cell replacement therapy for ischemic stroke using neural progenitor cells, which overexpress ADC that modulates excessive calcium levels, prevent mitochondrial membrane collapse, and strengthen intracellular calcium resistance [37]. The effect that agmatine has on the proliferation of neural progenitor cells, is thought to be in relation to the activation of extracellular-signal-regulated kinases (ERK) [60]. Calcium, particularly cytosolic and nuclear, is a key regulator for many cellular mechanisms such as proliferation, differentiation and apoptosis and even has an influence on cell cycle progression $[37,61,62]$.

Li et al. [9] have determined that the effect of agmatine on progenitor cells depends on both physiological and pathological conditions. For example, their previous studies displayed that agmatine increased the proliferation of hippocampal neural progenitors in chronically stressed mice [9]. However, this data contradicts Song et al. [60] reports that agmatine decreases the proliferation of cultured subventricular progenitors yet increased the differentiation to neurons by increasing MAP2-positive cells. These contradictory results are suggested to be due to the different origin of the cultured progenitor cells and different concentrations of agmatine [31]. Interleukin-1 Beta (IL-1 $\beta$ ) is widely known to be one of the most abundant pro-inflammatory cytokines in the mammalian brain; multiple studies suggested that an increase in IL$1 \beta$ levels will decrease cellular proliferation and decrease the number of post-mitotic neurons $[63,64]$. IL-1 $\beta$ expression in differentiating and proliferating neural progenitor cells can be prevented by interleukin 1 receptor antagonist inhibiting the binding of IL-1 $\beta$ to interleukin 1 type 1 receptor $[63,65]$. Strongly suggesting that agmatine can induce and modulate the differentiation and proliferation of neural progenitor cells by modulation IL-1 $\beta$ in neuroinflammatory conditions. 
Several studies have confirmed the importance of lethal-7 gene (let-7a) and ERK1/2 in the proliferation and self-renewal abilities of neural progenitor cells, let-7a having an inhibitory effect [66-68]. Song et al. [69] showed that $100 \mu \mathrm{l}$ of agmatine upregulates the differentiation of well-known neuronal markers NeuN and doublecortin protein family (DCX) and modulates the expression of let-7a, thus increasing neural progenitor differentiation $[66,69,70]$. Whereas ERK1/2 has an inducive effect on differentiation of neural progenitor cells in the subventricular zone, agmatine has been shown to regulate this process $[64-68,71,72]$. ERK1/2 and let-7a have a close relationship, ERK expression is decreased by the overexpression of let-7a, agmatine has been shown to promote ERK1/2 expression [64, 71, 72]. Thereby regulating let-7a and increasing cell survival and differentiation of neural progenitor cells [65]. Nuclear receptor, tailless homolog (TLX) is known to regulate neurogenesis in the adult hippocampus and is essential for regulating the neural progenitor cells undifferentiated state $[64,73]$. The signaling of ERK is promoted by agmatine, and TLX regulates p53 expression and explains the correlation between agmatine and TLX on the neural progenitor differentiation (Fig. 1) [73]. However, as ERK acts on many cellular processes, the exact relationship between ERK and let-7a requires further investigation. This data implies that agmatine regulates proliferation and differentiation of neural progenitor cells, again proving to be a promising therapeutic treatment to increase the differentiation of neural progenitor cells in inflammatory CNS diseases.

\section{Therapeutic Application of Agmatine on Neuronal Progenitor Cell Therapy in the Central Nervous System Disease}

There is an increasing amount of literature and data regarding the use of agmatine as a potential therapeutic agent for CNS diseases. It has been shown to emulate pre-existing mechanisms in the brain, making it a promising candidate for therapeutic treatment. As previously mentioned, agmatine can be found throughout the mammalian body and plays a role in maintaining homeostasis of the brain, heart and surrounding vascular structure by modulating calcium levels $[5,10,11,13]$. There is a wide range of neurological focuses and applications of agmatine such as Alzheimer's, stroke, epilepsy and psychological disorders such as stress, depression and addiction (Table 1) [2, 17-19, 31]. Recent studies have shown that agmatine protects neurons against glutamate toxicity by inhibiting the production of NO in microglia. This mechanism is controlled by NMDA receptors $[8,31$, 22]. It has been proposed that the agmatine related blockade of NMDA receptors may have an underlying antidepressant and anti-anxiety effect (Table 1) [13, 16, 23].

Table 1. Summary of novel approaches and therapeutic treatments for central nervous system diseases, showing neuroprotective effects of agmatine in animal models

\begin{tabular}{|c|c|c|c|c|}
\hline Disease & Experimental model & Target & Outcome & Reference \\
\hline Alzheimer's disease & $\begin{array}{l}\text { Streptozotocin-induced } \\
\text { Alzheimer's }\end{array}$ & $\begin{array}{l}\text { Neuron apoptosis via NMDA } \\
\text { receptors and inflammatory } \\
\text { cytokines (IL-1) }\end{array}$ & $\begin{array}{l}\text { Reduced accumulation of amyloid-beta protein, } \\
\text { phosphorylation of Tau peptide and } \\
\text { activation of insulin signal transduction }\end{array}$ & {$[24,57,72]$} \\
\hline Ischemic stroke & $\begin{array}{l}\text { Transient middle cerebral artery } \\
\text { occlusion ( } 2 \text { hours) }\end{array}$ & $\begin{array}{l}\text { Inhibition of neuronal NOS and } \\
\text { isoform NOS by reducing } \\
\text { production of NO }\end{array}$ & $\begin{array}{l}\text { Reduced infarct size and decreased production } \\
\text { of inflammatory cytokines }\end{array}$ & {$[26,33,34$} \\
\hline Parkinson's disease (PD) & $\begin{array}{l}\text { Intranasal administration of } \\
\text { МРTP }\end{array}$ & NMDA receptor \& NOS activity & Provided a $31 \%$ protection of PD & {$[5,71]$} \\
\hline Epilepsy & $\begin{array}{l}\text { Pentylenetetrazol induces } \\
\text { seizure (PTZ) }\end{array}$ & Extracellular glutamate & $\begin{array}{l}\text { Significantly reduce the severity and decreased } \\
\text { likelihood of seizure }\end{array}$ & {$[19,49]$} \\
\hline Depression & $\begin{array}{l}\text { Chronically induced stress } \\
\text { regimen }\end{array}$ & $\begin{array}{l}\text { Hippocampal neural progenitor } \\
\text { cells and } 5-\mathrm{HT}_{2} \text { receptor }\end{array}$ & $\begin{array}{l}\text { Increased neurogenesis and lessened depressive } \\
\text { behaviour }\end{array}$ & {$[9,18,25]$} \\
\hline Traumatic brain injury & $\begin{array}{l}\text { Lateral fluid percussion } \\
\text { injury (FPI) }\end{array}$ & Glutamate and $\mathrm{NO}$ activity & $\begin{array}{l}\text { Alleviation of motor and proprioception } \\
\text { deficits, cerebral infarct size and weight loss }\end{array}$ & {$[21,25]$} \\
\hline Spinal cord injury & $\begin{array}{l}\text { MASCIS (open field locomotor } \\
\text { scale) }\end{array}$ & M1 \& M2 Macrophage & $\begin{array}{l}\text { Reduce locomotive impairments by modulating } \\
\text { macrophage phenotypes }\end{array}$ & {$[26,70]$} \\
\hline Drug addiction & $\begin{array}{l}\text { Chronic morphine-treated } \\
\text { model }\end{array}$ & $\begin{array}{l}\text { Glutamate receptors in the } \\
\text { hippocampus }\end{array}$ & $\begin{array}{l}\text { Decreased glutamate release and prevented } \\
\text { down regulation of NMDA }\end{array}$ & {$[32]$} \\
\hline
\end{tabular}

IL, interleukin; NO, nitric oxide; NOS, nitric oxide synthases. 
As summarised in Table 1, Feng et al. [33] and Kim et al. $[26,32]$ were also able to show neuroprotective results against ischemic brain injury in MCAO models. The suppression of NO production by agmatine and the inhibition of nNOS expression and activity both showed mechanisms of neuroprotection against ischemic insult $[26,32]$. Targeting M1 and M2 macrophage activity, specifically BMP2, which reduces M1 macrophage in inflammatory conditions to reduce impenitent post spinal cord injury [74]. The inhibition of NOS activity and the blocking of NMDA receptors via agmatine provided partial protection of MPTP dopaminergic toxicity in Parkinson's disease models [75]. Song et al. [24] targeted NMDA receptors, Nrf2 and apoptosis of neurons to reduce the accumulation of amyloid-beta $(\mathrm{A} \beta)$ plaques and the phosphorylation of Tau proteins, thus ameliorating the cognitive decline of streptozotocin-induced Alzheimer's models. Similarly, agmatine reduced Alzheimer's pathologies in type 2 diabetes by regulating associated insulin signal molecules (Akt and IRS-1), reducing A $\beta$ plaques and improving hippocampal neural progenitor cell function [76]. The regulation of neural progenitor cells via agmatine, reducing the expression of IL-1 $\beta$ and thus promoting differentiation in neuroinflammatory conditions [64].

The therapeutic potential of agmatine on neural progenitor cells on psychological diseases such as high stress and depression is promising, with a significant amount of literature focusing on this relationship. The simulation and increased proliferation of neural progenitor cells in the hippocampus is known to decrease or reduce depressive-like symptoms [23]. With multiple studies displaying results that agmatine increases the proliferation of hippocampal progenitor cells, this mechanism provides an anti-depressive like effect $[9,18$, 34]. Targeting hippocampal progenitor cells in chronically stress-induced mice, agmatine increases neurogenesis, leading to a decrease in depressive behaviors [9].

Unfortunately, many of these applications face various technical, ethical and safety obstacles; mainly, heterogeneity, neuronal yield, and low survival rate [37]. Further study should target how agmatine influences the survival, differentiation, and maturation of the proliferated progenitor cells $[51,60]$. Utilizing the relationship between agmatine and its effect on neural progenitor cells shows very promising neuroprotective outcomes in various CNS disease models which may one day lead to clinical application.

\section{Conclusion}

The role of the agmatine as potential neuroprotectant for the treatment of acute brain disorders and spinal cord injury is being strongly recognized, along with a more detailed understanding of the mechanisms underlying this beneficial effect. There is also an increasing amount of data surrounding the use of neural progenitor cells as a key player for therapeutic treatments for various CNS disorders. The significant amount of literature showing positive effects of agmatine as a neuroprotective agent in in vitro and in vivo models of neurotoxicity and neural inflammation offer a favorable direction for future research and promising outcomes for therapeutic treatment for CNS diseases. Further investigation is required to comprehend the full effects of agmatine in neural progenitor cell research and to understand the mechanism and neuroprotective effect as well as the potential for therapeutic application.

\section{ORCID}

Renée Kosonen: https://orcid.org/0000-0003-1039-0682

Sumit Barua: https://orcid.org/0000-0001-5714-6105

Jong Youl Kim: https://orcid.org/0000-0002-8340-2894

Jong Eun Lee: https://orcid.org/0000-0001-6203-7413

\section{Author Contributions}

Conceptualization: JEL. Data acquisition: RK, SB. Data analysis or interpretation: RK. Drafting of the manuscript: RK. Critical revision of the manuscript: JYK, JEL. Approval of the final version of the manuscript: all authors.

\section{Conflicts of Interest}

No potential conflict of interest relevant to this article was reported.

\section{Acknowledgements}

The author would like to thank Dr. Sumit who has since changed his position to: senior researcher, KH Medical Co. Ltd, Gyeonggi-do, Republic of Korea.

This work was supported by the National Research Foundation of Korea (NRF) grant funded by the Korean Government (MSIT) (NRF-2021R1A2C2008034). 


\section{References}

1. Reis DJ, Regunathan S. Agmatine: an endogenous ligand at imidazoline receptors is a novel neurotransmitter. Ann N Y Acad Sci 1999;881:65-80.

2. Xu W, Gao L, Li T, Shao A, Zhang J. Neuroprotective role of agmatine in neurological diseases. Curr Neuropharmacol 2018;16:1296-305.

3. Behnisch T, Reymann KG. Co-activation of metabotropic glutamate and N-methyl-D-aspartate receptors is involved in mechanisms of long-term potentiation maintenance in rat hippocampal CA1 neurons. Neuroscience 1993;54:37-47.

4. Piletz JE, Aricioglu F, Cheng JT, Fairbanks CA, Gilad VH, Haenisch B, Halaris A, Hong S, Lee JE, Li J, Liu P, Molderings GJ, Rodrigues AL, Satriano J, Seong GJ, Wilcox G, Wu N, Gilad GM. Agmatine: clinical applications after 100 years in translation. Drug Discov Today 2013;18:880-93.

5. Raasch W, Regunathan S, Li G, Reis DJ. Agmatine, the bacterial amine, is widely distributed in mammalian tissues. Life Sci 1995;56:2319-30.

6. Molderings GJ, Burian M, Homann J, Nilius M, Göthert M. Potential relevance of agmatine as a virulence factor of Helicobacter pylori. Dig Dis Sci 1999;44:2397-404.

7. Osborne DL, Seidel ER. Gastrointestinal luminal polyamines: cellular accumulation and enterohepatic circulation. Am J Physiol 1990;258(4 Pt 1):G576-84.

8. Benamouzig R, Mahé S, Luengo C, Rautureau J, Tomé D. Fasting and postprandial polyamine concentrations in the human digestive lumen. Am J Clin Nutr 1997;65:766-70.

9. Li YF, Chen HX, Liu Y, Zhang YZ, Liu YQ, Li J. Agmatine increases proliferation of cultured hippocampal progenitor cells and hippocampal neurogenesis in chronically stressed mice. Acta Pharmacol Sin 2006;27:1395-400.

10. Raghavan SA, Dikshit M. Vascular regulation by the L-arginine metabolites, nitric oxide and agmatine. Pharmacol Res 2004;49:397-414.

11. Popolo A, Adesso S, Pinto A, Autore G, Marzocco S. L-Arginine and its metabolites in kidney and cardiovascular disease. Amino Acids 2014;46:2271-86.

12. Uzbay TI. The pharmacological importance of agmatine in the brain. Neurosci Biobehav Rev 2012;36:502-19.

13. Wang CC, Chio CC, Chang CH, Kuo JR, Chang CP. Beneficial effect of agmatine on brain apoptosis, astrogliosis, and edema after rat transient cerebral ischemia. BMC Pharmacol 2010;10:11.

14. Vlassara H, Bucala R, Striker L. Pathogenic effects of advanced glycosylation: biochemical, biologic, and clinical implications for diabetes and aging. Lab Invest 1994;70:138-51.

15. Li G, Regunathan S, Barrow CJ, Eshraghi J, Cooper R, Reis DJ. Agmatine: an endogenous clonidine-displacing substance in the brain. Science 1994;263:966-9.

16. Berkels R, Taubert D, Gründemann D, Schömig E. Agmatine signaling: odds and threads. Cardiovasc Drug Rev 2004;22:716.
17. Moretti M, Matheus FC, de Oliveira PA, Neis VB, Ben J, Walz R, Rodrigues AL, Prediger RD. Role of agmatine in neurodegenerative diseases and epilepsy. Front Biosci (Elite Ed) 2014;6:34159.

18. Watts D, Pfaffenseller B, Wollenhaupt-Aguiar B, Paul Géa L, Cardoso TA, Kapczinski F. Agmatine as a potential therapeutic intervention in bipolar depression: the preclinical landscape. Expert Opin Ther Targets 2019;23:327-39.

19. Feng Y, LeBlanc MH, Regunathan S. Agmatine reduces extracellular glutamate during pentylenetetrazole-induced seizures in rat brain: a potential mechanism for the anticonvulsive effects. Neurosci Lett 2005;390:129-33.

20. Olmos G, DeGregorio-Rocasolano N, Paz Regalado M, Gasull T, Assumpció Boronat M, Trullas R, Villarroel A, Lerma J, García-Sevilla JA. Protection by imidazol(ine) drugs and agmatine of glutamate-induced neurotoxicity in cultured cerebellar granule cells through blockade of NMDA receptor. Br J Pharmacol 1999;127:1317-26.

21. Kim JY, Lee YW, Kim JH, Lee WT, Park KA, Lee JE. Agmatine attenuates brain edema and apoptotic cell death after traumatic brain injury. J Korean Med Sci 2015;30:943-52.

22. Abe K, Abe Y, Saito H. Agmatine suppresses nitric oxide production in microglia. Brain Res 2000;872:141-8.

23. Santarelli L, Saxe M, Gross C, Surget A, Battaglia F, Dulawa S, Weisstaub N, Lee J, Duman R, Arancio O, Belzung C, Hen R. Requirement of hippocampal neurogenesis for the behavioral effects of antidepressants. Science 2003;301:805-9.

24. Song J, Hur BE, Bokara KK, Yang W, Cho HJ, Park KA, Lee WT, Lee KM, Lee JE. Agmatine improves cognitive dysfunction and prevents cell death in a streptozotocin-induced Alzheimer rat model. Yonsei Med J 2014;55:689-99.

25. Kuo JR, Lo CJ, Chio CC, Chang CP, Lin MT. Resuscitation from experimental traumatic brain injury by agmatine therapy. Resuscitation 2007;75:506-14.

26. Kim JH, Yenari MA, Giffard RG, Cho SW, Park KA, Lee JE. Agmatine reduces infarct area in a mouse model of transient focal cerebral ischemia and protects cultured neurons from ischemia-like injury. Exp Neurol 2004;189:122-30.

27. Freitas AE, Neis VB, Rodrigues ALS. Agmatine, a potential novel therapeutic strategy for depression. Eur Neuropsychopharmacol 2016;26:1885-99.

28. Regunathan S, Feinstein DL, Raasch W, Reis DJ. Agmatine (decarboxylated arginine) is synthesized and stored in astrocytes. Neuroreport 1995;6:1897-900.

29. Mancinelli L, Ragonese F, Cataldi S, Ceccarini MR, Iannitti RG, Arcuri C, Fioretti B. Inhibitory effects of agmatine on monoamine oxidase (MAO) activity: reconciling the discrepancies. EuroBiotech J 2018;2:121-7.

30. Regunathan S, Piletz JE. Regulation of inducible nitric oxide synthase and agmatine synthesis in macrophages and astrocytes. Ann N Y Acad Sci 2003;1009:20-9.

31. Liu Y, Lu GY, Chen WQ, Li YF, Wu N, Li J. Agmatine inhibits chronic morphine exposure-induced impairment of hippocampal neural progenitor proliferation in adult rats. Eur J 
Pharmacol 2018;818:50-6.

32. Kim JH, Kim JY, Jung JY, Lee YW, Lee WT, Huh SK, Lee JE. Endogenous agmatine induced by ischemic preconditioning regulates ischemic tolerance following cerebral ischemia. Exp Neurobiol 2017;26:380-9.

33. Feng Y, Piletz JE, Leblanc MH. Agmatine suppresses nitric oxide production and attenuates hypoxic-ischemic brain injury in neonatal rats. Pediatr Res 2002;52:606-11.

34. Moon SU, Kwon KH, Kim JH, Bokara KK, Park KA, Lee WT, Lee JE. Recombinant hexahistidine arginine decarboxylase (hisADC) induced endogenous agmatine synthesis during stress. Mol Cell Biochem 2010;345:53-60.

35. Mun CH, Lee WT, Park KA, Lee JE. Regulation of endothelial nitric oxide synthase by agmatine after transient global cerebral ischemia in rat brain. Anat Cell Biol 2010;43:230-40.

36. Jung HJ, Yang MZ, Kwon KH, Yenari MA, Choi YJ, Lee WT, Park KA, Lee JE. Endogenous agmatine inhibits cerebral vascular matrix metalloproteinases expression by regulating activating transcription factor 3 and endothelial nitric oxide synthesis. Curr Neurovasc Res 2010;7:201-12.

37. Kim JY, Kim JY, Kim JH, Jung H, Lee WT, Lee JE. Restorative mechanism of neural progenitor cells overexpressing arginine decarboxylase genes following ischemic injury. Exp Neurobiol 2019;28:85-103.

38. Bokara KK, Kwon KH, Nho Y, Lee WT, Park KA, Lee JE. Retroviral expression of arginine decarboxylase attenuates oxidative burden in mouse cortical neural stem cells. Stem Cells Dev 2011;20:527-37.

39. Cameron HA, Woolley CS, McEwen BS, Gould E. Differentiation of newly born neurons and glia in the dentate gyrus of the adult rat. Neuroscience 1993;56:337-44.

40. Ming GL, Song H. Adult neurogenesis in the mammalian brain: significant answers and significant questions. Neuron 2011;70:687-702.

41. Martínez-Cerdeño V, Noctor SC. Neural progenitor cell terminology. Front Neuroanat 2018;12:104.

42. Christie BR, Cameron HA. Neurogenesis in the adult hippocampus. Hippocampus 2006;16:199-207.

43. Gage FH. Mammalian neural stem cells. Science 2000;287:14338.

44. Goudarzi G, Hamidabadi HG, Bojnordi MN, Hedayatpour A, Niapour A, Zahiri M, Absalan F, Darabi S. Role of cerebrospinal fluid in differentiation of human dental pulp stem cells into neuron-like cells. Anat Cell Biol 2020;53:292-300.

45. Haratizadeh S, Nazm Bojnordi M, Darabi S, Karimi N, Naghikhani M, Ghasemi Hamidabadi H, Seifi M. Condition medium of cerebrospinal fluid and retinoic acid induces the transdifferentiation of human dental pulp stem cells into neuroglia and neural like cells. Anat Cell Biol 2017;50:107-14.

46. Chu MS, Chang CF, Yang CC, Bau YC, Ho LL, Hung SC. Signalling pathway in the induction of neurite outgrowth in human mesenchymal stem cells. Cell Signal 2006;18:519-30.

47. Goh EL, Ma D, Ming GL, Song H. Adult neural stem cells and repair of the adult central nervous system. J Hematother Stem
Cell Res 2003;12:671-9.

48. Kitamura T, Inokuchi K. Role of adult neurogenesis in hippocampal-cortical memory consolidation. Mol Brain 2014;7:13.

49. Cho JM, Shin YJ, Park JM, Kim J, Lee MY. Characterization of nestin expression in astrocytes in the rat hippocampal CA1 region following transient forebrain ischemia. Anat Cell Biol 2013;46:131-40.

50. Anacker C, Hen R. Adult hippocampal neurogenesis and cognitive flexibility - linking memory and mood. Nat Rev Neurosci 2017;18:335-46.

51. Doetsch F. A niche for adult neural stem cells. Curr Opin Genet Dev 2003;13:543-50.

52. Walz R, Castro RM, Velasco TR, Carlotti CG Jr, Sakamoto AC, Brentani RR, Martins VR. Cellular prion protein: implications in seizures and epilepsy. Cell Mol Neurobiol 2002;22:249-57.

53. Gould E, Tanapat P. Stress and hippocampal neurogenesis. Biol Psychiatry 1999;46:1472-9.

54. Deng W, Aimone JB, Gage FH. New neurons and new memories: how does adult hippocampal neurogenesis affect learning and memory? Nat Rev Neurosci 2010;11:339-50.

55. Drew MR, Hen R. Adult hippocampal neurogenesis as target for the treatment of depression. CNS Neurol Disord Drug Targets 2007;6:205-18.

56. Nacher J, Alonso-Llosa G, Rosell DR, McEwen BS. NMDA receptor antagonist treatment increases the production of new neurons in the aged rat hippocampus. Neurobiol Aging 2003;24:273-84.

57. Reis DJ, Regunathan S. Is agmatine a novel neurotransmitter in brain? Trends Pharmacol Sci 2000;21:187-93.

58. Seo S, Liu P, Leitch B. Spatial learning-induced accumulation of agmatine and glutamate at hippocampal CA1 synaptic terminals. Neuroscience 2011;192:28-36.

59. Rushaidhi M, Jing Y, Zhang H, Liu P. Participation of hippocampal agmatine in spatial learning: an in vivo microdialysis study. Neuropharmacology 2013;65:200-5.

60. Song HW, Kumar BK, Kim SH, Jeon YH, Lee YA, Lee WT, Park KA, Lee JE. Agmatine enhances neurogenesis by increasing ERK1/2 expression, and suppresses astrogenesis by decreasing BMP 2,4 and SMAD 1,5,8 expression in subventricular zone neural stem cells. Life Sci 2011;89:439-49.

61. Berridge MJ, Lipp P, Bootman MD. The versatility and universality of calcium signalling. Nat Rev Mol Cell Biol 2000;1:11-21.

62. Humeau J, Bravo-San Pedro JM, Vitale I, Nuñez L, Villalobos C, Kroemer G, Senovilla L. Calcium signaling and cell cycle: progression or death. Cell Calcium 2018;70:3-15.

63. Green HF, Treacy E, Keohane AK, Sullivan AM, O'Keeffe GW, Nolan YM. A role for interleukin-1 $\beta$ in determining the lineage fate of embryonic rat hippocampal neural precursor cells. Mol Cell Neurosci 2012;49:311-21.

64. Song J, Kumar BK, Kang S, Park KA, Lee WT, Lee JE. The effect of agmatine on expression of IL- $1 \beta$ and TLX which promotes neuronal differentiation in lipopolysaccharide-treated neural progenitors. Exp Neurobiol 2013;22:268-76.

65. Zunszain PA, Anacker C, Cattaneo A, Choudhury S, Musae- 
lyan K, Myint AM, Thuret S, Price J, Pariante CM. Interleukin$1 \beta$ : a new regulator of the kynurenine pathway affecting human hippocampal neurogenesis. Neuropsychopharmacology 2012;37:939-49.

66. Mullen RJ, Buck CR, Smith AM. NeuN, a neuronal specific nuclear protein in vertebrates. Development 1992;116:201-11.

67. Cimadamore F, Amador-Arjona A, Chen C, Huang CT, Terskikh AV. SOX2-LIN28/let-7 pathway regulates proliferation and neurogenesis in neural precursors. Proc Natl Acad Sci U S A 2013;110:E3017-26.

68. Sung SM, Jung DS, Kwon CH, Park JY, Kang SK, Kim YK. Hypoxia/reoxygenation stimulates proliferation through PKCdependent activation of ERK and Akt in mouse neural progenitor cells. Neurochem Res 2007;32:1932-9.

69. Song J, Oh Y, Kim JY, Cho KJ, Lee JE. Suppression of microRNA let-7a expression by agmatine regulates neural stem cell differentiation. Yonsei Med J 2016;57:1461-7.

70. Fu X, Brown KJ, Yap CC, Winckler B, Jaiswal JK, Liu JS. Doublecortin (Dcx) family proteins regulate filamentous actin structure in developing neurons. J Neurosci 2013;33:709-21.

71. Morrissey J, McCracken R, Ishidoya S, Klahr S. Partial cloning and characterization of an arginine decarboxylase in the kidney. Kidney Int 1995;47:1458-61.

72. Tocharus C, Puriboriboon Y, Junmanee T, Tocharus J, Ekthuwapranee K, Govitrapong P. Melatonin enhances adult rat hippocampal progenitor cell proliferation via ERK signaling pathway through melatonin receptor. Neuroscience 2014;275:31421.

73. Niu W, Zou Y, Shen C, Zhang CL. Activation of postnatal neural stem cells requires nuclear receptor TLX. J Neurosci 2011;31:13816-28.

74. Kim JH, Kim JY, Mun CH, Suh M, Lee JE. Agmatine modulates the phenotype of macrophage acute phase after spinal cord injury in rats. Exp Neurobiol 2017;26:278-86.

75. Gilad GM, Gilad VH, Finberg JP, Rabey JM. Neurochemical evidence for agmatine modulation of 1-methyl-4-phenyl1,2,3,6-tetrahydropyridine (MPTP) neurotoxicity. Neurochem Res 2005;30:713-9.

76. Kang S, Kim CH, Jung H, Kim E, Song HT, Lee JE. Agmatine ameliorates type 2 diabetes induced-Alzheimer's disease-like alterations in high-fat diet-fed mice via reactivation of blunted insulin signalling. Neuropharmacology 2017;113(Pt A):467-79. 